\title{
Classification of objects of tourism infrastructure in rural areas based on the use of historical, architectural and natural landscape potential on the example of Novosheshminsky region of the Republic of Tatarstan
}

\author{
Stepan Novikov ${ }^{1 *(0000-0001-9467-6789)}$ and Valeria Osina ${ }^{1(0000-0003-3698-2117)}$ \\ 1Kazan State University of Architecture and Engineering, 420043, Zelenaya st., Kazan, Russia
}

\begin{abstract}
Modern tourist trends are directed towards the undeveloped lands of the suburbs and rural areas, where, along with the agricultural and industrial orientation, the historical, architectural and natural landscape potential is preserved. To attract the tourist flow to the territory, routes are formed that allow identifying the historical significance and presenting this place taking into account ethnic, architectural, artistic and landscape features. Novosheshminsky region of the Republic of Tatarstan has a significant historical and cultural potential, is rich in natural resources, and flourishes in agriculture and horse breeding. For the sustainable development of the territory, it is proposed to form a tourist route that combines the key points of attracting tourists using the features of the tourist infrastructure. General logical methods-the analogy of domestic and foreign experience in organizing routes in rural areas, induction and observation, the theoretical method-historical and socio-cultural analysis of the Novosheshma region-revealed significant aspects in the organization of tourist infrastructure and methods of their correct use in these conditions. The result of the study was the creation of a tourist route on the territory of the Novosheshminsky region, followed by a proposal for the classification of tourist infrastructure objects necessary for its full functioning.

Keywords: rural tourism, historical and cultural heritage, historical and architectural heritage, natural and landscape potential, tourist, infrastructure, sustainable development.
\end{abstract}

\section{Introduction}

Modern tourism is a phenomenon of the twenty-first century. More than 150 out of 195 countries of the world are involved in it. Over the past decades, world tourism has shown strong growth. The tourism sector has become one of the dominant sectors of the world economy, involving natural, human, cultural, historical and other resources in its economic activity. In many countries and regions of the world, it acts as a catalyst for socio-economic development, for example, in Italy, Spain, France and other European countries. Recently,

\footnotetext{
* Corresponding author: to-stepa@mail.ru
} 
the tourist market has acquired great importance in Russia, actively developing and shaping a new image, both for domestic consumers and for foreign tourists. However, today the contribution of tourism to the Russian economy is not as significant as, for example, in a number of European countries, although it is characterized by high development dynamics. According to the Federal Tourism Agency, the share of tourism in Russia's GDP is $3.4 \%$, while in European countries the share can reach $10 \%$ [1,2].

In 2020, Russian tourism was facing serious obstacles in its development - a severe crisis associated with the rapid spread of a new type of virus (COVID-2019) across the planet [3]. The decline in global tourist flows has led to a reorientation from international tourism to domestic one, giving the latter a powerful incentive to develop. For Russia, this may mean an increase in the popularity of tourism in areas relatively untouched by anthropogenic impact. The suburbs and rural areas that are culturally, ecologically and naturally attractive to tourists who are not ready for mass travel may become the vectors of development. In this case, tourism acts as an important factor in regional development of territories, stimulating the development of deserted areas, abandoned land, backward areas, extreme areas with historical and architectural or landscape potential, but, for various reasons, not previously had the opportunity to organize a quality tourism infrastructure. The World Tourism Organization assigns rural tourism as one of the priority areas of tourism in Russia, which is also due to the special natural conditions of the country [4].

At the beginning of its development in the 1990s rural tourism provided a narrow range of services, including accommodation in ecologically clean conditions, acquaintance with the life and traditions of the native villagers, etc. Modern trends point to its close interaction with the cultural and cognitive function. Synthesized routes are based not only on cultural features, but also on architectural and natural monuments [5-7]. Such areas are wealthy and attract tourists. The dissemination of cultural and cognitive tourism in the territories of villages contributes not only to creating a favorable socio-economic environment, but also the preservation and use of historical and architectural heritage, through the creation of tourist routes with the participation of tangible cultural objects. In their study Eleni Oikonomopoulou, Ekaterini T. Delegou, John Sayas, Antonia Moropoulou outline approaches to the preservation and protection of cultural heritage on the example of routes on the island of Chios in Greece. The research paper analyzes the role of cultural routes in the protection and promotion of cultural heritage in rural areas within the framework of sustainable and spatial development of territories $[8,9]$. In addition to the preservation and restoration of architectural heritage, the combination of rural and cultural and cognitive types of tourism in the regions reveals the natural potential of the area. It should be remembered that rural tourism, unlike mass tourism, has no harmful effects on the environment and, at the same time, makes a significant contribution to regional development [10]. The historic landscape features combined with the culture of the place create a unique atmosphere and jobs for local people.

Region of Russia, where the above-mentioned areas of tourism are actively developing, is the Republic of Tatarstan. This is primarily due to the desire to revive the history, traditions and customs of peoples, to increase the level of culture and social significance of settlements, to create an additional source of income and new jobs, as well as comprehensive development of the infrastructure of villages. There are 18 municipal districts in the Republic of Tatarstan, each of which is able to provide various services in the field of rural tourism. Novosheshminsky region can become a potential territory for the development of a full-fledged infrastructure of «green» tourism with a historical and cultural vector. The territory, located in the central part of Tatarstan, has a significant cultural heritage, rich in natural resources, characterized by thriving agriculture and horse breeding. In order to attract the flow of tourists in Novosheshminsky region it is necessary to create a holistic tourism infrastructure. 
In order to ensure sustainable development of the territory, restore existing and recreate lost historical and cultural monuments, attract investment and create new tourist destinations for people who want to spend their holidays away from the big and noisy city, in Novosheshminsk it is necessary to form a variability of routes, based on the needs of different types of tourists and develop an appropriate typology of infrastructure.

Thus, it is required to analyze the structure of the construction of tourist routes in the territories of rural settlements, studying domestic and foreign experience in organizing routes, to identify the typology of rural tourism infrastructure facilities for the subsequent formation of quality tourist environment in the territory of Novosheshminsky region of the Republic of Tatarstan.

\section{Materials and methods}

The first part of the study presents the theoretical framework necessary for the further development of future routes, taking into account the specifics of the place, the historical and cultural component of the territory and the availability, location and functioning of the existing tourism infrastructure.

The formation of routes is influenced by many factors. The key factor is the consideration of heterogeneous preferences of tourist groups. Weimin Zheng, Zhixue Liao have written a lot about it in their research. In their work they pay attention to the heuristic approach for designing personalized tourist routes for heterogeneous tourist groups. This approach can provide tourist groups with more diversified, realistic and personalized itineraries $[11,12]$. Jiaying Lyua, Huan Huanga, Zhenxing Maob studied the preferences of middle-aged and elderly people in long-term tourism in rural areas by the example of staying in rural areas of China. The study reveals the dimensions of tourists' choice of rural destinations for long-term tourism. These dimensions are comfort, well-being, countryside, publicity and familiarity [13]. The second important factor is the state of the material heritage of the territory which the routes will be created in [14]. The third factor when creating a route is the necessity to make an inventory of all the objects that will be used along the way. Such objects include all kinds of tourism infrastructure: tourist accommodation, catering establishments, transportation, entertainment and navigation. For a comfortable stay of a tourist on the territory, it is necessary to analyze the availability of all infrastructure components, their condition, add the missing ones, and think in advance about the trajectory of people's movement. For example, rural tourism often involves the accommodation of tourists in houses with their hosts. Such an experience allows guests to feel the characteristics of the culture of the people, to become a participant in rural life and learn about the traditions. A study by Suh-hee Choi, Xiaoxiao Fu shows that various strategies are used to welcome visitors, including how travelers prepare for the reception, attract guests with selective information about the destination, and design itineraries. Such strategies relate to how they use the local tourist space shaped by their personal interest, previous leisure pattern, and their leisurely exploration of the destination [15]. But if tourists do not want to live in a house with the hosts, they can stay in tourist hubs, which are specially designed for this [16].

In the second part of the study a full-scale, historical and socio-cultural analysis of the territory of Novosheshminsky region, in which the features of the natural and landscape components are identified, the number and physical condition of architectural monuments is considered and the quality of existing facilities of tourism infrastructure is assessed.

Novosheshminsk is a historical settlement, as a military fortress of old times played a prominent role in the history of the Russian state to protect the Trans-Kama settlements from nomadic peoples in the XVII - XVIII centuries. Around Novosheshminskaya fortress, built in 1652, to strengthen the military power founded Peter and Paul, Catherine, 
Archangel, Volchaya and Cheremukhovaya slobodas (large villages inhabited by free peasants). The sloboda was inhabited by the military, who were given tax exemptions and sent to various military services. But after the final pacification of all nomadic tribes and peoples and their annexation to Russia, all the military were invited to switch to a peaceful way of life, that is, to independent living and financial support. The presence of abundant forest around created favorable conditions for the construction of housing, the presence of predatory fur-bearing animals provided an opportunity to make and sell furs, and the presence of fish in the Sheshma River and nearby lakes allowed to engage in fishing. People began to cut forests, engage in agriculture and raise livestock. Subsequently, Novosheshminsk became a large and prosperous village.

According to the historical data, the river Sheshma, flowing in the middle of the village, divided Novosheshminsk into two parts. The half, located on the mountain, was called the city part, and behind the river - the sloboda part. Here, near the Sheshma River, during the winter holidays there were all kinds of ceremonial gatherings and sledding of young people with decorated horses, especially on Shrovetide. In the afternoon and in the evening there were fist fights between the inhabitants of the two territories.

In 2005, the Sheshma River was recognized as a natural monument of regional importance. In addition to the river Sheshma (natural monument) there are rich natural resources in the area - Urganchin botanical reserve for the conservation of Adonis and Korzhinskogo slopes (state nature reserves). Objects of cultural heritage, located on the territory of Novosheshminsky district, are witnesses and true sources of cultural and historical development. Valleys and moats - monuments of bygone times - for the most part destroyed, as a result of bygone years (Fig. 1). However, on the way to Petropavlovskaya and Ekaterininskaya slobodas there are still remains of ancient fortified settlements surrounded by double, and even triple system of deep ditches and high ramparts, as well as other defensive structures. To date, 8 monuments of history and culture have been identified in the area. In the village of Novosheshminsk there is Trinity Church (1794) - an architectural construction of baroque epoch. In Arkhangelskaya, Ekaterininskaya and Petropavlovskaya slobodas historical churches remained with similar dimensional-planning solutions and built in volumetric composition «ship»: the bell tower, refectory, the main volume of the church «octagon on the square» and the apse. The temples were built approximately at the same time, but the condition and preservation of the objects are different: the Church of the Ascension (1876) in Arkhangelskaya is an example of the eclectic period. The Church of Peter and Paul being a model of religious architecture with elements of classicism and Baroque, partly functioning, is in emergency condition. There is a collapse of the main dome and the delamination of paintings in the interior. The Church of the Trinity (1875-1883) being a mixture of pseudo-Renaissance and pseudo-Russian style, the church does not function and arrives in ruined condition. In addition to temples in Novosheshminsky region in the village Yerykly bridge track Kazan - Orenburg (18971907) and a mosque in 1907, and other historically important objects are preserved [17].
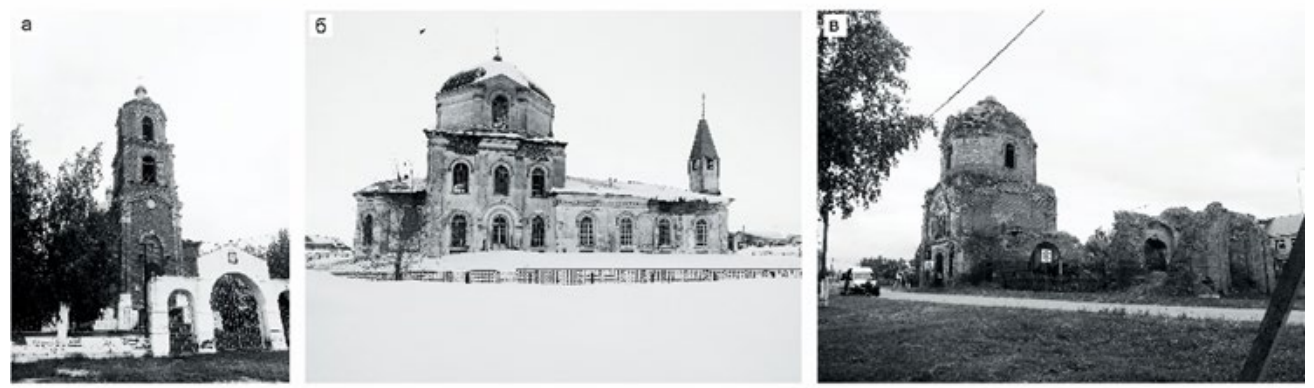
Fig. 1. Orthodox churches in the settlements of Novosheshminsky region:

a) Arkhangelskaya sloboda, Voznesenskaya Church. Photo by S. V. Novikov, July 2019;

b) Petropavlovskaya sloboda ,. Church of Peter and Paul Photo by S. V. Novikov, July 2019;

c) Ekaterininskaya sloboda, Trinity Church. Photo by S. V. Novikov, July 2019.

\section{Results}

This study identified the following factors affecting the structure of the tourist route:

1. Personalization is an important part in the creation of the route. It is necessary to focus on the preferences of different population groups in tourism. This will ensure the competent scripting of the tourist itinerary and allow each tourist to feel an individual approach.

2. The state of architectural and natural heritage of the territory will allow including objects in the tourist route and functional load to connect them in a single chain. In addition, the condition affects the drafting of leisure time for tourists.

3. The quality of the components of the tourism infrastructure. It is important to create a comfortable environment through the use of 5 main types of tourism infrastructure: tourist accommodation facilities, catering establishments, transport, entertainment and navigation. By means of the full-scale territory analysis of the route creation the existing objects are identified, their condition and the possibility to function in the tourist route are evaluated. Necessary components for tourist service are added during the route generation [18].

Conducted historical, socio-cultural and full-scale analysis of the territory of Novosheshminsky region for the creation of tourist routes and infrastructure has shown that, despite the historical value of Novosheshminsky region and a large number of natural resources of interest for the organization of excursion, scientific or event tourism, the territory does not have a sufficient level of tourism infrastructure organization. The transport component does not have the possibility of tourist transport passage; the means of accommodation are limited to one mini-hotel for 4 rooms, and public catering establishments -4 cafes. There is no navigation and information on the territory. The preserved monuments of cultural heritage do not work, they do not belong either to the objects of demonstration or to the objects of «adaptation». Valuable witnesses of history and architecture are gradually turning into ruins, as work on their restoration and reconstruction is not carried out. Every year Novosheshminsk hosts various entertainment events and festivals, both conventional and religious, despite the lack of specialized equipped venues. The same can be said about recreational spaces.

To organize a high-quality tourism infrastructure on the territory of Novosheshminsky region it is necessary, first of all, to create the main and secondary tourist routes. The concept of routes consists in the synthesis of objects of historical, cultural and ethnic heritage, agricultural and natural resources of the region into a coherent tourist system, united by a common scenario [19]. The components of the system can be combined into smaller routes, which will give the tourist the possibility to choose his/her own type of rest.

The introduction of the main route, connecting the villages with a ring road, is a proposal. The center of the composition will be Novosheshminsk village (Fig. 2). Having different historical, cultural and natural resources of the settlements it ispossible to organize an integral environment due to the specifics of their character and historical features [20]. Due to the unsatisfactory condition or loss of some objects of cultural heritage, the restoration, reconstruction and recreation of iconic sites and ensembles for the sake of the historical and cultural development of the territory is implied. The stone houses in the Arkhangelskaya sloboda may become an excellent means of recreating the atmosphere of the old village life (Fig. 3). Orthodox churches will be wonderful examples of restored religious architecture. Restoration of the Novosheshma fortress will stimulate the interest of scientists, archaeologists, history buffs and tourists. Leisure time organization involving 
natural complexes and agricultural land will allow guests of the region to get closer acquainted with the culture, traditions and customs of the settlements, to become participants in the processes of economic activities and to feel the connection with nature.

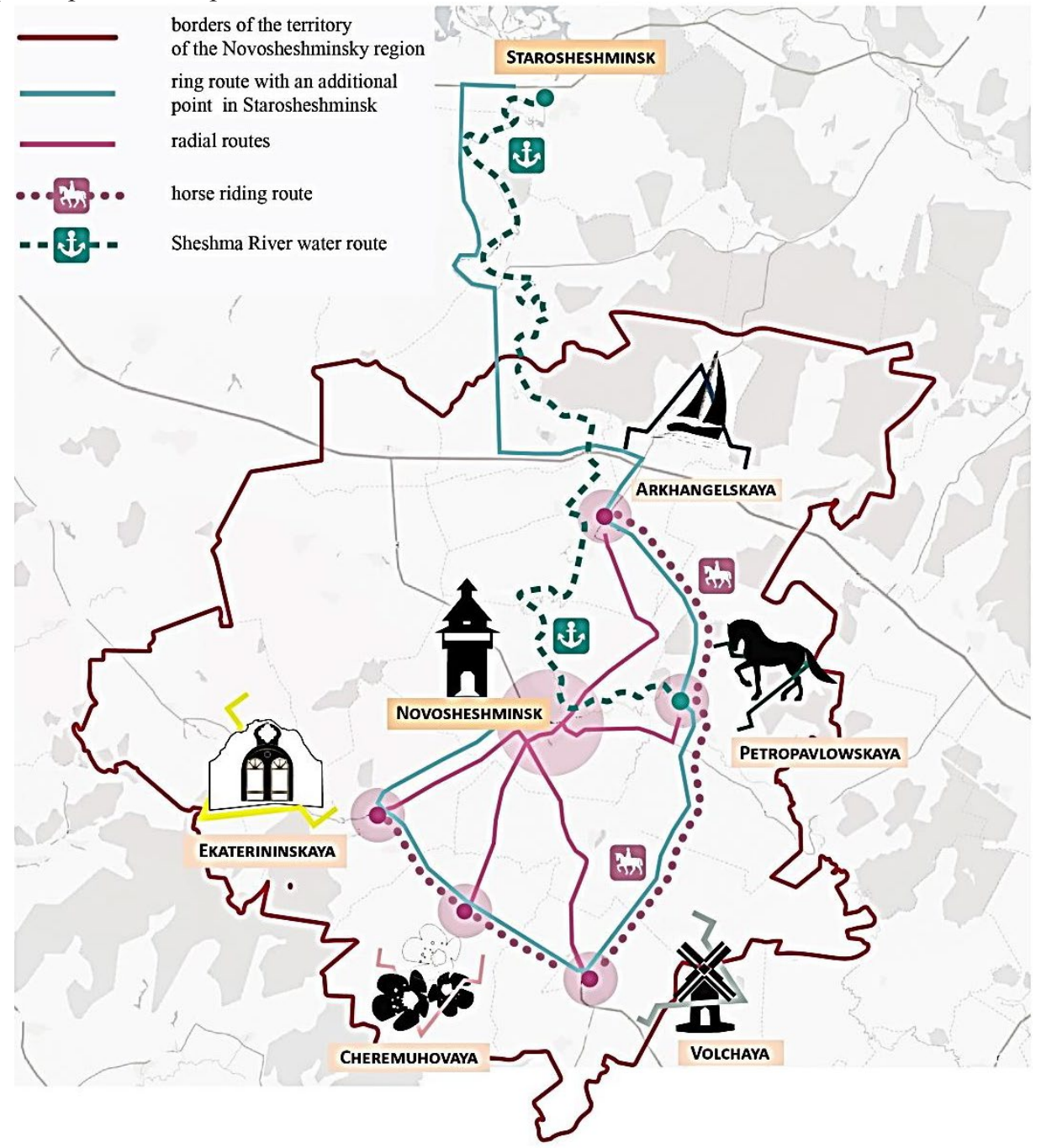

Fig. 2. Map of tourist routes of the Novosheshminsky region. Offer.
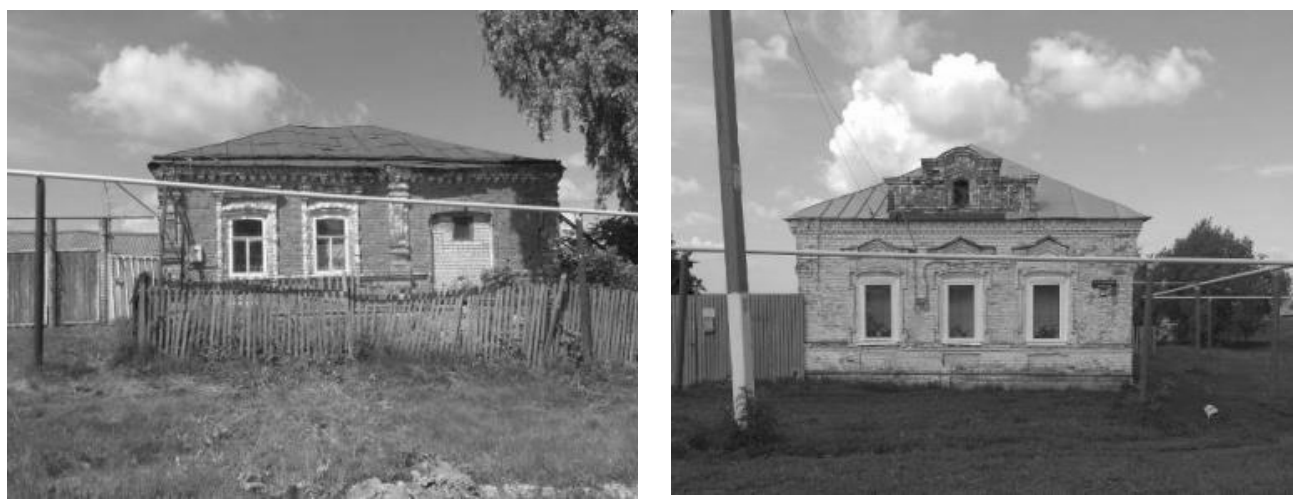
Fig. 3. Stone houses in the Arkhangelskaya settlement. Photo by S. V. Novikov, June 2020.

In addition to attractions, the route involves the presence of basic elements of tourism infrastructure: accommodation and catering facilities, etc. Typology of service facilities will vary depending on the location: in the center - the village of Novosheshminsk - they will be presented by a complex hotel, in the Petropavlovskaya sloboda it is assumed an agro-farm based on the stables the cultivation of ecologically clean products, and in all other settlements - house residents are ready to host guests for a holiday and to introduce them to the way of life.

Ways of moving between the different points of stops varies. Tourists can move not only by auto and bicycle transport, but also on horseback, and rafting on the Sheshma River, where possible (there are areas of shallow water). Each stopping point will be equipped with a navigation system for easy orientation along the route. The tourist center is proposed to be located in the village of Novosheshminsk.

\section{Discussion}

The study examines the reasons for the focus on domestic tourism in the world and in Russia. Modern trends dictate the desire of city dwellers to relax in the countryside. The demand for a rural type of tourism has led to an increase in the quality of the organization of routes, a variety of tourist activities forms and functional equipment of infrastructure facilities.

Based on the studied theoretical framework, a number of factors influencing the formation of a rural cultural and cognitive route has been identified. One of the stages of creating a tourist route is a comprehensive analysis (theoretical, full-scale) of the territory. One of the potential territories for tourist development could be Novosheshminsky region of the Republic of Tatarstan.

Analysis of the area have shown that, despite the historical value of the identified cultural sites and natural landscape potential that are of interest for the organization of excursion, scientific or event tourism, the territory does not have a sufficient level of tourism infrastructure organization.

The consequence of the study was a proposal to create a rural cultural and educational route with the subsequent development of the tourism infrastructure typology.

\section{Conclusion}

The development of a comprehensive tourism architectural infrastructure on the territory of Novosheshminsky region will stimulate the construction of domestic and foreign (international) tourism with the further attraction of investments and the creation of new jobs. Local cultural identity can be reflected in the aesthetics of modern architectural and urban design of the district. Rural tourism in combination with cultural and cognitive can give an intensive impetus in the dynamics of sustainable development of the district rural area. Materials of this study, namely the classification of tourism infrastructure objects in rural areas based on the use of historical-architectural and natural landscape potential, can become a model for the design principles in the regions of the Republic of Tatarstan and other regions of the Russian Federation.

\section{References}


1. L. Andrades, F. Dimanche, Destination competitiveness and tourism development in Russia: Issues and challenges, Tourism Management, 62, 360-376 (2017) DOI:10.1016/j.tourman.2017.05.008

2. I. V. Loguntsova, Marketing aspects of tourism management (ARGAMAK-Media, Moscow, 2019)

3. J. Abbas, R. Mubin, P. Terhemba Iorember, M. Razag, G. Mamirkulova, Exploring the impact of COVID-19 on tourism: transformational potential and implications for a sustainable recovery of the travel and leisure industry, Current Research in Behavioral Sciences, 2, 100033 (2021) DOI: 10.1016/j.crbeha.2021.100033

4. The Tourism Development Strategy of the Russian Federation for the period up to 2035, approved by the Decree of the Government of the Russian Federation of September 20, 2019. No. 2129-R. S. 50, URL: http://government.ru/docs/37906

5. G. Ismagilova, L. Safiullin, 1. Gafurov, Using Historical Heritage as a Factor in Tourism Development, Procedia - Social and Behavioral Sciences, 188, 157-162 (2015) DOI: $10.1016 /$ j.sbspro.2015.03.355

6. G. Richards, Cultural tourism: A review of recent research and trends, Journal of Hospitality and Tourism Management, 36, 12-21 (2018) DOI:10.1016/j.jhtm.2018.03.005

7. D. Vorontsov, A. Shikhalev, K. Semushina, Using of Cultural Heritage in the Socioeconomic Development Strategy of the EU Regions, Procedia - Social and Behavioral Sciences, 188, 163-169 (2015) DOI: 10.1016/j.sbspro.2015.03.358

8. E. Oikonomopoulo, E. T. Delegou, J. Sayas, A. Moropoulou, An innovative approach to the protection of cultural heritage: The case of cultural routes in Chios Island, Greece, Journal of Archaeological Science: Reports, 14, 742-757 (2017) DOI: 10.1016/j.jasrep.2016.09.006

9. S. Hatan, A. Fleischer, A. Tchetchik, Economic valuation of cultural ecosystem services: The case of landscape aesthetics in the agritourism market, Ecological Economics, 184, 107005 (2021) DOI: 10.1016/j.ecolecon.2021.107005

10. S. Khanra, A. Dhir, P. Kaur, M. Mäntymäki, Bibliometric analysis and literature review of ecotourism, Toward sustainable development, 37 (2021) DOI:10.1016/j.tmp.2020.100777

11. W. Zheng, Z. Liao, Using a heuristic approach to design personalized tour routes for heterogeneous tourist groups, Tourism Management, 72, 313-325 (2019) DOI:10.1016/j.tourman.2018.12.013

12. M. Valeriu Vana, S. Malaescu, Cultural Thematic Tourism Itineraries: Mediators of Success, Procedia Economics and Finance, 39, 642-652 (2016) DOI:10.1016/S22125671(16)30311-2

13. J. Lyua, H. Huanga, Z. Maob, Middle-aged and older adults' preferences for long-stay tourism in rural China, Journal of Destination Marketing \& Management, 19, 100552 (2021) DOI: 10.1016/j.jdmm.2020.100552

14. D. Rossa, G. Saxenaa, F. Correiaa, P. Deutz, Archaeological tourism: A creative approach, Annals of Tourism Research, 67, 37-47 (2017) DOI: 10.1016/j.annals.2017.08.001

15. S. Choi, X. Fu, Hosting friends and family as a sojourner in a tourism destination, Tourism Management, 67, 47-58 (2018) DOI: 10.1016/j.tourman.2017.12.023

16. I. Paulino, L. Prats, P. Schofield, Tourist hub consumption systems: Convenient flexibility versus administrative constraint, Journal of Hospitality and Tourism Management, 41, 69-79 (2019) DOI:10.1016/j.jhtm.2019.09.006

17. A. M. Taranov, Cultural heritage of the Republic of Tatarstan Administrative areas, Illustrated catalog (Nicentry, Moscow 2017) 
18. C. Xiang, J. Xiao qin, L. Yin, Study on the rural ecotourism resource evaluation system, Environmental Technology \& Innovation, 20, 101131 (2020) DOI: 10.1016/j.eti.2020.101131

19. A. B. Minyazova, G. N. Aidarova, Approaches and principles of the formation of the architectural and urban planning environment of rural ecotourism in Tuscany, Izvestiya KGASU, 1(47), 121-129 (2019)

20. X. Yu, H. Xu, Cultural heritage elements in tourism: A tier structure from a tripartite analytical framework, Journal of Destination Marketing \& Management, 13, 39-50 (2019) DOI:10.1016/j.jdmm.2019.05.003 